\title{
Strategi Pengembangan Industri Kecil Gula Aren Di Kecamatan Basidondo Kabupaten Tolitoli
}

\author{
Development Strategi Of A Small Industrial Sugar Ini Kecamatan Basidondo Tolitoli \\ District
}

\author{
Andhy Saputra ${ }^{1}$, Ramlawati $^{2}$, Hilmi $^{3}$ \\ ${ }^{1}$ Prodi Manajemen, Sekolah Tinggi Ilmu Ekonomi Mujahidin \\ (andhy.saputra@stiemujahidin.ac.id) \\ ${ }^{2,3}$ Prodi Ekonomi Pembangunan, Sekolah Tinggi Ilmu Ekonomi Mujahidin \\ (ramlawati@stiemujahidin.ac.id) \\ (hilmi@stiemujahidin.ac.id)
}

\begin{abstract}
ABSTRAK
Industri kecil mempunyai peranan yang penting dalam penyerapan tenaga kerja, pemerataan pendapatan, dan meningkatkan kesejahteraan masyarakat. Industri kecil gula aren di Kabupaten Tolitoli terdapat di Kecamatan Basidondo, antara lain : Desa Kinapasan, Labonu, Kayu Lompa, Ogosipat, Kongkomos, Galandau, Silondou dan Sibaluton. Masalah dalam penelitian ini adalah bagaimana strategi pengembangan industri kecil gula aren di Kecamatan Basidondo Kabupaten Tolitoli. Tujuan yang ingin di capai dalam penelitian ini adalah mengetahui bagaiman strategi pengembangan industri kecil gula aren di Kecamatan Basidondo Kabupaten Tolitoli. Populasi dalam penelitian ini adalah 64 unit usaha yang tersebar di beberapa desa di Kecamatan Basidondo Kabupataen Tolitoli. Pengambilan sampel dalam penelitian ini menggunakan metode accidental sampling dengan sampel terpilih sejumlah 30 responden. Analisis data dilakukan dengan menggunakan analisis matrik SWOT. Kesimpulan yang diperoleh berdasarkan analisis matrik SWOT, strategi yang dapat dilakukan untuk memberdayakan industri kecil gula aren di Kecamatan Basidondo Kabupaten Tolitoli adalah dengan strategi konsentrasi melalui integrasi horizontal. Artinya strategi yang diterapkan lebih defensif, yaitu menghindari kehilangan penjualan dan kehilangan profit yang disebabkan oleh ancaman-ancaman. Saran yang diberikan adalah dengan mempertahankan ciri khas cita rasa produk dan meningkatkan kualitas produk dengan cara menciptakan inovasi dalam pengemasan produk, penambahan jenis produk agar memiliki daya tarik yang tinggi agar tetap mampu bersaing dengan produk lain.
\end{abstract}

Kata Kunci : Strategi, pengembangan industri kecil, analisis SWOT

\section{ABSTACT}

A small industry has an important role in absorbing labor, distributing income, and improving people's welfare. Small palm sugar industries in Tolitoli Regency are located in Basidondo District, including Kinapas, Labonu, Kayu Lompa, Ogosipat, Kongkomos, Galandau, Silondou, and Sibaluton Villages. The problem in this research is how the strategy of developing the small palm sugar industry in Basidondo District, Tolitoli Regency. The aim to be achieved in this research is to know how the strategy for developing small palm sugar industries in Basidondo District, Tolitoli Regency. The population in this study was 64 business units scattered in several villages in Basidondo District, Tolitoli Regency. Sampling in this study using method accidental sampling with a selected sample of 30 respondents. Data analysis was performed using the SWOT matrix analysis. The conclusion obtained is based on the SWOT matrix analysis, the strategy that can be done to empower the small palm sugar industry in Basidondo District, Tolitoli Regency is a concentration strategy through horizontal integration. This means that the strategy to be implemented is more defensive, namely avoiding lost sales and lost profits caused by threats. The advice given is to maintain the characteristic taste of the product and improve product quality by creating innovations in product packaging, adding types of products to have high attractiveness to remain able to compete with other products

KeyWords : Strategy, small industry development, SWOT analysis 


\section{PENDAHULUAN}

Dalam era globalisasi dewasa ini menuntut bangsa Indonesia untuk maju mengejar ketertinggalannya di semua sektor. Sektor industri merupakan salah satu sektor utama sebagai mesin penggerak ekonomi nasional, di mana sektor industri merupakan salah satu prioritas pembangunan ekonomi, dengan tetap memperhatikan pembangunan di sektor lain.

Melihat potensi industri kecil yang sangat baik, tidak berarti dalam proses usahanya tidak menghadapi hambatan dan tantangan. Seperti yang dikatakan Anoraga (2002:245), bahwa usaha kecil menghadapi berbagai tantangan dan kendala seperti kualitas sumber daya manusia yang rendah; tingkat produktifitas dan kualitas produk dan jasa rendah; kurangnya teknologi dan informasi; faktor produksi; sarana dan prasarana belum memadai; aspek pendanaan dan pelayanan jasa pembiayaan; iklim usaha belum mendukung, dan koordinasi pembinaan belum baik. Namun demikian ada peluang yang dapat dimanfaatkan oleh UKM dalam kegiatan usahanya, seperti: adanya komitmen pemerintah; ketersediaan sumber daya alam yang beraneka ragam dan lain-lain.

Industri kecil pedesaan mempunyai arti penting dalam usaha mengurangi tingkat kemiskinan di pedesaan atau dengan kata lain diharapkan dapat meningkatkan kesejahteraan hidup masyarakat pedesaan (Mubyarto,1986:78).

Kecamatan Basidondo merupakan salah satu wilayah dari 10 Kecamatan di Kabupaten Tolitoli yang memiliki industri kecil bersumber daya lokal yaitu berupa industri kecil pembuatan gula aren. Kabupaten Kendal mempunyai jumlah industri kecil dengan berbagai jenis kelompok industri.

Industri kecil gula aren di Kabupaten Tolitoli terdapat di Kecamatan Basidondo, antara lain : Desa Kinapasan, Labonu, Kayu Lompa, Ogosipat, Kongkomos, Galandau, Silondou dan Sibaluton.
Pada penelitian Mustafa Abd. Rahim pada tahun 2019, dikatakan bahwa salah satu masalah dalam pengembangan industri gula aren adalah keterampilan SDM pengolah dan kualitas produk gula aren. Menurutnya, salah satu strategi untuk mengembangkan industri kecil tersebut adalah dengan mencoba untuk menjual dan mendistribusikan hasil produksi kewilayah lain yang lebih luas.

Gula aren adalah pemanis yang dibuat dari nira yang berasal dari tandan bunga jantan pohon enau atau pohon aren. Gula aren biasanya juga diasosiasikan dengan segala jenis gula yang dibuat dari nira, yaitu cairan yang dikeluarkan dari bunga pohon dari keluarga palma. Gula aren tidak sama dengan gula jawa. Perbedaan gula aren dengan gula jawa (gula kelapa) antara lain dalam hal :

1. Sumber niranya Gula aren dibuat dari nira pohon aren, sedangkan gula jawa atau gula kelapa dibuat dari nira pohon kelapa.

2. Komposisi kimanya Komposisi gula sederhana dan gula komplek antara gula aren dan gula kelapa sangat berbeda. Juga kandungan zat gizi dan non gizinya sangat berbeda.

3. Sifat fisiknya Salah satu sifat fisik yang mencolok perbedaannya adalah warnanya. Gula aren lebih gelap dibandingkan gula kelapa. Hal ini terkait dengan proses pemanenan nira

Adapun tujuan dalam penelitian ini adalah Menganalisis strategi pengembangan yang tepat untuk diterapkan pada industri kecil gula aren di Kecamatan Basidondo Kabupaten Tolitoli.

\section{METODE PENELITIAN}

Jenis penelitian ini adalah penelitian deskriptif merupakan analisis yang berguna untuk menggambarkan variabel yang diteliti (Arikunto, 2000: 213). Yaitu hasil penelitian ini hanya untuk menggambarkan atau melukiskan keadaan suatu obyek penelitian 
pada saat sekarang berdasarkan fakta-fakta yang tampak atau sebagaimana adanya.

Adapun metode pengumpulan data dalam penelitian ini adalah sebagai berikut :

1. Wawancara

Wawancara dilakukan untuk memperoleh data dari pengusaha pada industri kecil gula aren di Kecamatan Basidondo maupun dari instansi-instansi terkait. Wawancara dilakukan untuk mengumpulkan data tentang kekuatan, kelemahan, peluang dan ancaman dari industri kecil gula aren.

2. Dokumentasi

Metode ini digunakan untuk mengumpulkan data fisik dan kondisi usaha industri gula aren di Kecamatan Basidondo Kabupaten Tolitoli.

3. Kuesioner/Angket

Pemilihan model tersebut diharapkan responden akan memberikan jawaban secara objektif dan detail.

Jenis data yang digunakan dalam penelitian ini adalah data sekunder dan primer. Sumber data sekunder dalam penelitian ini, didapatkan dari Instansi atau Dinas terkait di Kabupaten Tolitoli, Dinas tersebut diantarannya : Badan Pusat Statistik Kabupaten Tolitoli, dan Dinas Perindustrian dan Perdagangan Kabupaten Tolitoli. Data primer didapatkan langsung dari observasi langsung ke lokasi yaitu di Kecamatan Basidondo.

Populasi yaitu sekelompok orang, kejadian atau segala sesuatu yang mempunyai karakteristik tertentu (Indriantoro dan Supomo, 1999). Masalah populasi timbul terutama pada penelitian yang menggunakan metode survey sebagai teknik pengumpulan data. Populasi dalam penelitian ini adalah industri kecil gula aren di Kecamatan Basidondo dipilihnya daerah tersebut karena daerah tersebut terdapat beberapa (banyak) industri kecil gula aren yang berjumlah 64 unit usaha.

Sampel adalah bagian yang menjadi objek sesungguhnya dari suatu penelitian, dan metodologi untuk memilih dan mengambil industri-industri masuk ke dalam sampel yang representatif disebut sampling (Soeratno dan Arsyad, 1999). Sampel dalam penelitian ini diambil dengan menggunakan metode accidental sampling yaitu pengambilan sampel secara acak. Pengrajin industri kecil gula aren yang dijadikan sebagai sampel dalam penelitian ini. Diambil 30 sampel dari 64 populasi, diantaranya dari Desa Kinapasan berjumlah 3 unit usaha. Di Desa Labonu 5 berjumlah unit usaha, Desa Kayu Lompa dengan 4 unit usaha, di Desa Kongkomos dengan 6 unit usaha, di Desa Sibaluton dengan 8 unit usaha dan di Desa Galandau dengan 4 unit usaha.

Adapun teknik analisis dalam penelitian ini adalah sebagai berikut :

\section{Analisis SWOT}

Analisis SWOT adalah identifikasi berbagai faktor secara sistematis untuk merumuskan faktor-faktor pendorong dan penghambat pertumbuhan dan perkembangan sektor industri kecil gula aren. Analisis ini didasarkan pada logika yang dapat memaksimalkan kekuatan (strength) dan peluang (opportunities), namun secara bersamaan dapat meminimalkan kelemahan (weakness) dan ancaman (treats). Hal ini disebut dengan analisis situasi. Model yang paling popular untuk analisis situasi adalah analisis SWOT (Rangkuti, 2008:19). Analisis SWOT membandingkan faktor eksternal peluang (opportunities) dan ancaman (treats) dengan faktor internal kekuatan (strength) dan kelemahan (weakness), untuk menghasilkan analisis yang tepat.

Analisis Strength, Weakness, Opportunity, Threat (SWOT) yang dapat dijabarkan sebagai berikut :

1) Peluang (Opportunity)

Peluang adalah situasi penting yang menguntungkan dalam lingkungan usaha. Kecenderungan kecenderungan penting merupakan salah satu sumber peluang.

2) Ancaman (Threat)

Ancaman adalah situasi penting yang tidak menguntungkan dalam suatu perusahaan. Semakin banyaknya 
persaingan, lambatnya pertumbuhan pasar, meningkatnya kekuatan tawarmenawar, perubahan teknologi, serta peraturan baru atau yang direvisi dapat menjadi ancaman bagi keberhasilan perusahaan Memahami peluang dan ancaman utama yang dihadapi perusahaan dapat membantu para pengambil keputusan.

3) Kekuatan (Strength)

Kekuatan adalah sumber daya, keterampilan atau keunggulan lain terhadap pesaing dan kebutuhan pasar. Kekuatan adalah kompetensi khusus (distinctive competence) yang memberikan keunggulan komparatif bagi perusahaan. Kekuatan dapat terkandung dalam sumber daya keuangan, citra, kepemimpinan pasar, dan faktor-faktor lain. Peneliti ingin menganalisis kekuatan dalam hal strategi perusahaan

4) Kelemahan (Weakness)

Kelemahan adalah faktor keterbatasan atau kekurangan dalam sumber daya keterampilan dan kapabilitas yang secara serius menghambat kinerja efektif.

\section{Matriks Pengembangan SWOT}

Matriks pengembangan SWOT merupakan alat-alat yang dipakai untuk mengukur faktor-faktor strategi perusahaan. Matriks ini dapat menghasilkan empat sel kemungkinan alternatif srategi. Menurut Suwarsono (2009:245) adapun kriteria alternatif strategi perusahaan dapat dijelaskan sebagai berikut :

1) Strategi $\mathrm{SO}$

Strategi ini dibuat berdasarkan jalan pikiran perusahaan, yaitu dengan memanfaatkan seluruh kekuatan untuk merebut peluang sebesar-besarnya.

2) Strategi ST

Yaitu strategi dalam menggunakan kekuatan yang dimiliki perusahaan untuk mengatasi ancaman.

3) Strategi WO

Strategi yang diterapkan berdasarkan pemanfaatan peluang yang ada dengan cara meminimalkan kelemahan.

\section{4) Strategi WT}

Strategi yang didasarkan pada kegiatan yang bersifat defensit dan berusaha meminimalkan kelemahan yang ada serta menghindari ancaman.

\section{HASIL DAN PEMBAHASAN \\ Analisis Lingkungan Ekternal}

Lingkungan eksternal meliputi dua aspek penting yaitu peluang dan ancaman. Pembuat gula aren di Kecematan Basidondo harus mampu mengatasi segala ancaman yang datang dan mengambil peluang yang ada dan dapat menembus pasar.

Dari lingkungan eksternal dapat diidentifikasi peluang dan ancaman yang mungkin timbul dari lingkungan bisnis. Perubahan dan pengaruh lingkungan terhadap bisnis bisa menguntungkan dan sering pula bisa berupa ancaman, oleh karena itu, perlu dianalisis. Hanya unsur lingkungan yang diidentifikasi dominan pengaruhnya terhadap perusahaan yang dianalisis, sementara yang lain diabaikan.

Langkah analisis lingkungan eksternal meliputi :

1) Identifikasi dan seleksi sejumlah variabel/elemen-elemen yang relevan berpengaruh pada prospek perusahaan,

2) Identifikasi variabel yang merupakan peluang dan yang merupakan ancaman,

3) Pemberian bobot masing-masing elemen,

4) Pemberian nilai masing-masing elemen,

5) Menghitung nilai tertimbang dengan menjumlahkan bobot dikalikan nilai,

6) Menjumlahkan nilai tertimbang seluruh variabel/elemen-elemen.

\section{Analisis Elemen Peluang (Opportunities)}

Adapun nilai lingkungan eksternal elemen peluang diperoleh dari hasil jawaban atas pernyataan kuesioner yang dibagikan kepada para pembuat gula aren , sedangkan hasil pembobotan yaitu setiap elemen variabel peluang haruslah memiliki total bobot sama dengan $1(1,00)$ yang dapat dilihat pada tabel.1 berikut ini : 
Tabel. 1

Perhitungan Jumlah Nilai Tertimbang Peluang Pada Usaha Pembuat Gula Aren

Di Kecamatan Basidondo Kabupaten Tolitoli

\begin{tabular}{rlrcc}
\hline $\mathbf{N o}$ & \multicolumn{1}{c}{ Elemen Peluang } & Nilai & Bobot & B x N \\
\hline $\mathbf{1}$ & Produk merupakan produk tradisional dan ciri khas daerah & 3,27 & 0,259 & 0,847 \\
\hline $\mathbf{2}$ & Pangsa pasar masih luas & 3,57 & 0,283 & 1,010 \\
\hline $\mathbf{3}$ & Permintaan yang semakin meningkat & 3,34 & 0,265 & 0,885 \\
\hline $\mathbf{4}$ & Pemberian jasa-jasa pelatihan dan pendampingan & 2,44 & 0,193 & 0,471 \\
\hline & Total nilai tertimbang peluang & 12,62 & 1 & 3,213
\end{tabular}

Sumber : Data primer diolah, 2020

Dari tabel.1 di atas menunjukkan bahwa perhitungan jumlah nilai tertimbang peluang berjumlah 3,213 yang berarti bernilai positif dan cukup besar, utamanya pada elemen pernyataan kuesioner peluang dengan nilai tertinggi dimana seluruh responden berjumlah 30 orang (pembuat gula aren) memberikan jawaban sangat setuju yang menyatakan bahwa pembuat gula aren di Kecamatan Basidondo bahwa gula aren yang merupakan produk tradisional dan ciri kas daerah masih memiliki pangsa pasar yang luas dengan masih tingginya tingkat permintaan dari masyarakat.

Tabel. 2

Perhitungan Jumlah Nilai Tertimbang Ancaman Pada Usaha Pembuat Gula Aren

Di Kecamatan Basidondo Kabupaten Tolitoli

\begin{tabular}{ccccc}
\hline $\mathbf{N o}$ & Elemen Ancaman & Nilai & Bobot & B x N \\
\hline $\mathbf{1}$ & Banyaknya pesaing antar perajin & 3,40 & 0,276 & 0,938 \\
\hline $\mathbf{2}$ & Banyaknya barang pengganti substitute & 3,30 & 0,268 & 0,884 \\
\hline $\mathbf{3}$ & Bahan baku susah diperoleh & 2,70 & 0,221 & 0,597 \\
\hline $\mathbf{4}$ & Inovasi dalam corak monoton & 2,90 & 0,235 & 0,681 \\
\hline & Total nilai tertimbang ancaman & 12,30 & 1 & 3,10
\end{tabular}

Sumber : Data primer diolah, 2020

Berdasarkan tabel. 2 diatas, menunjukkan bahwa perhitungan jumlah nilai tertimbang ancaman berjumlah 3,10 yang berarti bernilai positif dan cukup besar, utamanya pada elemen pernyataan kuesioner ancaman dengan nilai tertinggi dimana seluruh responden sebanyak 30 orang (pembuat gula aren) di Kecamatan Basidondo memberikan jawaban sangat penting yang menyatakan bahwa semakin banyaknya pesaing baru, munculnya produk pengganti

\section{Analisis Elemen Ancaman (Threats)}

Adapun nilai lingkungan variabel eksternal elemen ancaman diperoleh dari hasil jawaban atas pernyataan pada kuesioner yang dibagikan kepada seluruh pembuat gula aren yang berjumlah 30 orang di Kecamatan Basidondo Kabupaten Tolitoli, sedangkan hasil pembobotan yaitu setiap elemen variabel peluang haruslah memiliki total bobot sama dengan $1(1,00)$ yang dapat dilihat pada tabel.2 berikut ini : substitute, bahan baku yang sulit diperoleh serta inovasi dalam corak monoton.

\section{Analisis Lingkungan Internal}

Lingkungan internal meliputi dua aspek pennting yaitu kekuatan dan kelemahan. para pembuat gula aren di Kecamatan Basidondo Kabupaten Tolitoli harus mampu mengatasi segala kelemahan yang datang dan menggunakan kekuatan yang ada untuk dapat 
menembus pasar. Analisis lingkungan internal berusaha untuk mengidentifikasi jumlah variabel pokok yang berada di dalam para usaha pembuat gula aren di Kecamatan Basidondo Kabupaten Tolitoli yang diperlukan serta memiliki pengaruh nyata.

Langkah-langkah analisis variabel internal pemasaran dapat dilakukan sebagai berikut :

\section{Menentukan pesaing dekat yang mengganggu,}

2. Identifikasi elemen yang merupakan kekuatan dan kelemahan,

3. Pembobotan masing-masing elemen tersebut,

4. Penilaian atas elemen-elemen tersebut,
5. Menghitung nilai tertimbang dengan cara mengalikan bobot denga nilai,

6. Menjumlahkan nilai tertimbang internal.

\section{Analisis Elemen Kekuatan (Strengths)}

Adapun nilai lingkungan internal elemen kekuatan diperoleh dari hasil jawaban atas pernyataan kuesioner yang dibagikan kepada konsumen berjumlah 30 orang yaitu para pembuat gula aren di Kecamatan Basidondo Kabupaten Tolitoli, sedangkan hasil pembobotan yaitu setiap elemen kekuatan haruslah memiliki total bobot sama dengan 1 $(1,00)$ yang dapat dilihat pada tabel 3 . berikut ;

Tabel. 3

Perhitungan Jumlah Nilai Tertimbang Kekuatan Pada Usaha Pembuat Gula Aren

Di Kecamatan Basidondo Kabupaten Tolitoli

\begin{tabular}{clccc}
\hline No & \multicolumn{1}{c}{ Elemen Kekuatan } & Nilai & Bobot & B x N \\
\hline $\mathbf{1}$ & Banyaknya jumlah pohon aren & 4,07 & 0,276 & $\mathbf{1 , 1 2 3}$ \\
\hline $\mathbf{2}$ & SDM yang memadai & 3,60 & 0,244 & $\mathbf{0 , 8 7 8}$ \\
\hline $\mathbf{3}$ & Peralatan / sarana produksi terjangkau & 3,70 & 0,251 & $\mathbf{0 , 9 2 9}$ \\
\hline $\mathbf{4}$ & Adanya pedagang pengepul & 3,37 & 0,229 & $\mathbf{0 , 7 7 2}$ \\
\hline & Total nilai tertimbang kekuatan & 14,74 & 1 & $\mathbf{3 , 7 0 2}$
\end{tabular}

Sumber : Data primer diolah, 2020

\section{Analisis Elemen Kelemahan (Weaknesses)}

Adapun nilai lingkungan internal elemen kelemahan diperoleh dari hasil jawaban atas pernyataan kuesioner yang dibagikan kepada seluruh responden yang berjumlah 30 orang yaitu para (pembuat gula aren) di Kecamatan
Basidondo Kabupaten Tolitoli, sedangkan hasil pembobotan yaitu setiap elemen variabel peluang haruslah memiliki total bobot sama dengan $1(1,00)$ yang dapat dilihat pada tabel. 4 berikut ini :

Tabel. 4

Perhitungan Jumlah Nilai Tertimbang Kelemahan Pada Usaha Pembuat Gula Aren

Di Kecamatan Basidondo Kabupaten Tolitoli

\begin{tabular}{clccc}
\hline No & \multicolumn{1}{c}{ Elemen Kelemahan } & Nilai & Bobot & B x N \\
\hline $\mathbf{1}$ & Proses produksi yang relatif lama & 3,30 & 0,286 & 0,944 \\
\hline $\mathbf{2}$ & Kurangnya media promosi & 2,84 & 0,246 & 0,699 \\
\hline $\mathbf{3}$ & Kualitas produk yang belum standarisasi & 2,74 & 0,238 & 0,652 \\
\hline $\mathbf{4}$ & Kemampuan manajerial dalam mengelola usaha & 2,64 & 0,230 & 0,607 \\
\hline & Total nilai tertimbang kelemahan & 11,52 & 1 & 2,902
\end{tabular}

Sumber : Data primer diolah, 2020

Berdasarkan tabel. 4 diatas menunjukkan bahwa perhitungan jumlah nilai tertimbang elemen kelemahan berjumlah 2,903 yang berarti bernilai positif dan cukup besar, 
utamanya pada elemen pernyataan kuesioner kelemahan dengan nilai tertinggi dimana seluruh responden yang berjumlah 30 orang (pembuat gula aren) di Kecamatan Basidondo Kabupaten Tolitoli menyatakan proses-proses produksi yang relatif lama, kurangnya media promosi, kualitas produk yang belum standarisasi serta kemampuan manajerial dalam mengelola usaha masih sangat kurang.

\section{Matrik Internal dan Eketernal}

Adapun matriks pengembangan Strategi internal dan ekternal pada usaha pembuatan gula aren dapat dilihat pada tabel. 5 Berikut ini

Tabel. 5

Matriks Pengembangan Strategi Internal dan Ekternal pada usaha pembuatan gula aren di Kecamatan Basidondo Kabupaten Tolitoli

\begin{tabular}{|c|c|c|c|c|}
\hline Eksternal & Ideal & Mature & Speculative & Trouble \\
\hline Dominant Position & $\mathrm{I}$ & $\mathrm{I}$ & I $^{*}$ & $\mathrm{I}$ \\
\hline Strong Position & I & $\mathrm{I}$ & $\mathrm{I}$ & I \\
\hline Favourable Position & I & I & I & $\mathrm{D}$ \\
\hline Tenable Position & I & I & $\mathrm{D}$ & $\mathrm{D}$ \\
\hline Weak Position & I & $\mathrm{D}$ & $\mathrm{D}$ & $\mathrm{D}$ \\
\hline Avoid Position & $\mathrm{D}$ & $\mathrm{D}$ & $\mathrm{D}$ & $\mathrm{D}$ \\
\hline
\end{tabular}

Sumber : Data primer diolah, 2020

*) Posisi usaha gula aren di Kecamatan Basidondo Kabupaten Tolitoli

$\mathrm{I}=\mathrm{D}=$ Divest

Invest Berdasarkan tabel. 5 posisi bisnis usaha gula aren di Kecamatan Basidondo Kabupaten Tolitoli, jika dilihat dari sudut lingkungan internal dan lingkungan eksternal usaha berada pada posisi invest artinya perusahaan mempunyai keunggulan yang sangat besar serta lingkungan dunia usaha dimasuki memberi peluang yang besar pula, maka pemilihan atas strategis sudah baik.

Menurut Suwarsono (2009:247) analisis SWOT merupakan langkah-langkah kongkrit yang sebaiknya dilakukan para pembuat gula aren di Kecamatan Basidondo Kabupaten
Tolitoli, berdasarkan pengembangan matriks posisi bisnis usaha maka akan dirumuskan berbagai alternatif strategi dapat dirumuskan berdasarkan model analisis matriks SWOT. Strategi utama yang dapat disarankan terdapat empat kategori yaitu strategi S-O, strategi S-T, strategi W-O dan strategi W-T. Analisis ini menggunakan data yang telah diperoleh, adapun keunggulan dari penggunaan model ini adalah mudah memformulasikan strategi berdasarkan gabungan faktor lingkungan eksternal dan internal perusahaan. Maka matriks SWOT dapat dilihat pada tabel.6 berikut ini 
Tabel. 6

Analisis SWOT

Pada Usaha Pembuatan Gula Aren Di Kecamatan Basidondo KabupatenTolitoli

\begin{tabular}{|c|c|c|}
\hline $\begin{array}{l}\text { Ekternal } \\
\text { Internal }\end{array}$ & Peluang (Opportunities) & Ancaman (Threats) \\
\hline $\begin{array}{c}\text { Kekuatan } \\
(\text { Strengths })\end{array}$ & $\begin{array}{c}\text { Strategi S-O : } \\
\text { Usaha pembuatan gula aren diKecamatan } \\
\text { Basidondo Kabupaten Tolitoli dengan } \\
\text { menciptakan strategi yang menggunakan } \\
\text { kekuatan untuk memanfaatkan peluang } \\
\text { yang ada }\end{array}$ & $\begin{array}{c}\text { Strategi S-T : } \\
\text { Usaha pembuatan gula aren di Kecamatan } \\
\text { Basidondo Kabupaten Tolitoli dengan } \\
\text { memilimalisir ancaman dengan kekuatan } \\
\text { yang ada }\end{array}$ \\
\hline $\begin{array}{c}\text { Kelemahan } \\
\text { (Weaknesses) }\end{array}$ & $\begin{array}{c}\text { Strategi W-O : } \\
\text { Usaha pembuatan gula aren di Kecamatan } \\
\text { Basidondo Kabupaten Tolitoli dengan } \\
\text { menciptakan strategi yang menggunakan } \\
\text { peluang untuk mengatasi kelemahan yang } \\
\text { ada }\end{array}$ & $\begin{array}{l}\text { Strategi W-T : } \\
\text { Usaha pembuatan gula aren di Kecamatan } \\
\text { Basidondo Kabupaten Tolitoli dengan } \\
\text { menciptakan strategi yang meminimalisir } \\
\text { kelemahan dan menghindari ancaman }\end{array}$ \\
\hline
\end{tabular}

Sumber : Data Primer (diolah), 2020

Berdasarkan tabel. 6 di atas, hasil analisis matriks SWOT bahwa kinerja perusahaan dapat ditentukan oleh kombinasi faktor lingkungan ekternal dan faktor lingkungan internal, kombinasi kedua faktor tersebut dapat dijelaskan sebagai berikut :

\section{Strategi S-O (Strengths - Opportunities)}

Adapun strategi S-O yang dapat ditempuh oleh para pembuat gula aren di Kecamatan Basidondo Kabupaten Tolitoli adalah sebagai berikut :

1) Memaksimalkan pembuatan produk Gula aren merupakan produk tradisional dan ciri khas daerah dengan memanfaatkan banyaknya jumlah pohon aren sebagai bahan baku untuk di produksi dalam jumlah banyak,

2) Dengan adanya SDM yang memadai maka pemilik usaha dapat masuk ke pangsa pasar yang lebih luas,

3) Dengan tersedianya peralatan/sarana untuk dapat memproduksi gula aren yang mana terjangkau maka pemilik usaha dapat memenuhi permintaan yang semakin meningkat,

4) Memanfaatkan adanya pedagang pengepul gula aren di daerahnya sehingga dapat memproduksi gula aren dalam jumlah banyak dengan pemberian jasa-jasa pelatihan dan pemdampingan dari ahli yang berada didaerah yang sama.

\section{Strategi S-T (Strengths - Threats)}

1) Meskipun banyaknya pesaing atau perajin gula aren di suatu lingkungan yang sama namun tersedia banyak jumlah pohon aren di sekitar sehingga tetap dapat memproduksi gula aren setiap hari,

2) Meskipun mulai bermunculan barang pengganti substitute namun konsumen yang sudah terbiasa dengan produk lokal gula aren tentunya dengan adanya SDM yang memadai maka gula aren yang dihasilkan akan tetap dicari konsumen,

3) Meskipun bahan baku utama air nira pada pohon aren akan sulit di peroleh pada waktu-waktu tertentu namun tetap dapat diproduksi karena peralatan/sarana produksi yang terjangkau sehingga para pembauat gula aren tetap memproduksi meskipun dalam jumlah kecil.

4) Adanya pedagang pengepul gula aren sehingga pembuat dapat memproduksi gula aren secara terus menerus meskipun inovasi dalam corak monoton namun konsumen membutuhkan rasa dan kualitas bukan sekedar bentuk gula aren. 


\section{Strategi W-O (Weaknesses - Opportunities)}

Strategi ini merupakan gabungan dari faktor lingkungan internal kekuatan (strengths) dan faktor lingkungan eksternal peluang (opportunities) strategi ini dibuat berdasarkan jalan pikiran perusahaan, yaitu menggunakan peluang untuk mengatasi kelemahan yang ada. Adapun strategi W-O yang ditempuh oleh para pembuat gula aren di Kecamatan Basidondo Kabupaten Tolitoli adalah sebagai berikut :

1) Meskipun proses produksi yang cukup lama yang mana gula aren merupakan produk tradisional dan ciri khas daerah namun gula aren tetap diburu konsumen sebagai salah satu bahan makanan yang digunakan setiap hari,

2) Meskipun media promosi masih sangat kurang namun pangsa pasar gula aren masih tetap luas khususnya di daerah yang sama.

3) Meskipun produk yang belum standarisasi namun permintaan gula aren semakin meningkat dalam waktu-waktu tertentu seperti pada bulan suci ramadhan tiba.

4) Meskipun kemampuan manajerial dalam mengelola usaha namun adanya jasa-jasa pelatihan dan pendampingan dari ahli baik itu dari keluarga ataupun orang sekitar sehingga produksi gula aren tetap berlangsung setiap hari.

\section{5) Strategi W-T (Weaknesses - Threats )}

1) Proses produksi gula aren yang relatif lama serta banyaknya pesaing atau perajin gula aren bermunculan namun gula aren tetap diproduksi untuk memenuhi kebutuhan konsumen,

2) Kurangnya media promosi dan banyaknya barang pengganti substitute namun gula aren masih menjadi salaha satu bahan baku campuran makanan dan kue tradisional yang di sukai masyarakat,

3) Kualitas produk yang belum standarisasi dan bahan baku susah di peroleh utamanya dimusim kemarau panjang namun gula aren masih menjadi salah satu alternatif pilihan meskipun harganya mahal akan tetap dibeli konsumen,

4) Kemampuan manajerial dalam mengelola usaha dan inovasi dalam corak monoton namun gula aren tetap diburu oleh konsumen tradisional.

\section{KESIMPULAN DAN SARAN}

Berdasarkan analisis data yang telah dilakukan maka dapat kesimpulan penelitian ini adalah sebagai berikut :

1. Jalur pemasaran pada industri kecil gula aren masih pendek. Harus melakukan pengelolaan persediaan dengan lebih baik agi, menurut Yonasfiko Hendratmiko (2010) salah satu metode persediaan yang cocok dan efektif untuk digunakan adalah metode EOQ (Economic Order Quantity) .

2. Bahan baku industri kecil gula aren di Kecamatan Basidondo tersedia dengan mudah. Bahan baku yang didapat tidak hanya didapat dari satu pohon aren saja, tetapi dari beberapa pohon aren.Ketersediaan air nira aren ini sangat mempengaruhi keberlangsungan industri gula aren.

3. Berdasarkan analisis SWOT, strategi yang dapat dilakukan untuk pengembangan industri kecil gula aren di Kecamatan Basidondo Kabupaten Tolitoli adalah dengan strategi invest.

Adapun Saran yang dapat diajukan dalam penelitian ini adalah sebagai berikut :

1. Bagi Pemerintah daerah

a. Dalam hal pemasaran, pemerintah lebih sering mengikutsertakan para pengusaha dalam event-event tertentu sehingga gula aren di Kecamatan Basidondo Kabupaten Tolitoli di kenal oleh masyarakat luas.

b. Dalam hal permodalan, pemerintah bisa memberi bantuan dalam bentuk hibah/ pinjaman lunak kepada para pengusaha untuk mengembangkan usahanya. 
c. Untuk dapat menunjang keberhasilan perkembangan usaha, hendaknya pemerintah menciptakan pertumbuhan iklim usaha yang kondusif.

2. Bagi Pembuat gula aren

a. Mengadakan studi banding ke daerah pembuat gula aren yang berada di luar Kabupaten Tolitoli agar para pengusaha gula aren mendapat tambahan ilmu, bisa meningkatkan inovasi produk dan saling bertukar pengalaman dengan pengrajin daerah lain demi kemajuan usaha.

b. Perlunya melakukan inovasi dalam segi pengemasan yang lebih modern.

c. Meningkatkan kegiatan promosi-promosi yang lebih banyak seperti melalui media massa.

\section{UCAPAN TERIMA KASIH}

Puji syukur dipanjatkan kehadirat ALLAH SWT yang telah melimpahkan ridho dan karunia-Nya sehingga penyusunan jurnal peneliti dapat terselesaikan. Adapun jurnal ini berjudul : " Strategi Pengembangan Industri Kecil Gula Aren di Kecamatan Basidondo Kabupaten Tolitoli ".

Penyelesaian jurnal ini dapat berjalan dengan lancar berkat bantuan dari berbagai pihak oleh karena itu pada kesempatan ini peneliti menyampaikan ucapan terima kasih kepada :

1. Seluruh civitas pada Sekolah Tinggi Ilmu Ekonomi (STIE) Mujahidin Tolitoli yang telah memberikan kesempatan dan sebagai wadah peneliti dalam memenuhi impian untuk sukses dalam kehidupan,

2. Pemerintah dan seluruh masyarakat di Kecamatan Basidondo Kabupaten Tolitoli khususnya para pembuat gula aren di daerah tersebut.

\section{DAFTAR PUSTAKA}

Arikunto, Suharsimi. 2000. Manajemen Penelitian. Rineka Cipta : Jakarta.

$$
\text { ,2006. Prosedur }
$$

Penelitian Suatu Pendekatan Praktik. Rineka Cipta : Jakarta.
Anoraga, Pandji dan Djoko Sudantoko. 2002. Koperasi, Kewirausahaan, dan Usaha Kecil. Jakarta: PT Rineka Cipta.

Indriantoro dan Supomo. 1999. Metodologi Penelitian Bisnis untuk Akuntansi dan Manajemen. Edisi Pertama. BPFE Yogyakarta. Yogyakarta.

Mubyarto. 1986. Pengantar Ekonomi Pertanian. LP3ES: Yogyakarta.

Mustafa Abd. Rahim. 2019. Strategi pengembangan usaha gula aren di Desa Sumberharjo Kecamatan Moilong. Fakultas Pertanian Unismuh Luwuk

Rangkuti, Freddy. 2008. Analisis SWOT Teknik Membedah Kasus Bisnis, Jakarta: PT. Gramedia Pustaka Utama.

Soeratno dan Arsyad. 1999. Mikro Ekonomi Teori Pengantar edisi ketiga. PT.Rajagrafindo Persada : Jakarta.

Suwarsono. 2009. Analisis SWOT. Jakarta : Salemba Empat.

Yonasfiko Hendratmiko. 2010. Analisis Pengendalian Persediaan Bahan Baku pada Industri Kecil Menengah Mebel di Kota Kendal. FEKON UN Semarang 